\title{
NOTE ON THE DOCUMENTS
}

Translators belong to a class of professionals whom the world takes pleasure in reviling. Like estate agents, auditors and accountants, they enjoy a function similar to that performed by the sin-eaters of certain primitive communities, whose job was to absorb others' sense of wrongdoing through the consumption of a ritual meal. Should we fail to enjoy, let alone understand, a novel or a poem, we can always lay the guilt on a faulty rendering, with a swipe or two at syntax and vocabulary for good measure. ${ }^{1}$

In writing these words, Jonathan Keates was reviewing the recent reprint of George Steiner's great study of translation and the translator's art, After Babel. ${ }^{2}$ His opening salvo does little to inspire with joy and optimism one who is about to present to the reader, in translation, a complex set of sources for the history of western and central European Jews in the fifteenth and sixteenth centuries.

The selection of documents which is presented here was originally written in a wide range of languages - Latin, Hebrew, French, German, Portuguese, Spanish and Italian. All these languages were spoken, or at least understood, by fifteenth- and sixteenth-century Europeans, in various countries, whether they were Jews or Christians - or, in the case of Spain, Muslims. It may be thought that, when it comes to 'historical' as opposed to 'literary' texts, there is no need for the translator to agonise over the problem raised by Keates. The author of the work he reviewed had, however very different ideas on the subject.

Steiner wrote, in a passage he describes as a 'truism', that 'Translation exists because men speak different languages'. ${ }^{3}$ His expressed purpose in composing the chapter which precedes this observation was to demonstrate that, since linguistic chaos exists in the world, and has done, in metaphor at least, ever since the building of the tower of Babel [see Glossary], all communications, even within the expression of a single human 'language', require an exercise in decoding. Such observations clearly apply at least as much to 'historical documents' as they do to the literary texts which normally exercise the professional translator and his or her readership.

1 Jonathan Keates in The Independent, 8 May 1993.

2 George Steiner, After Babel. Aspects of language and translation, Oxford, 1975, 1993.

3 Steiner, After Babel, 1975 edn, p. 49. 
Because of the centrality of Judæo-Christian experience in the life and history of Europeans, in the fifteenth and sixteenth centuries and since, and particularly because both these religions so much revere their written texts, or 'Scriptures', on which faith and practice are meant to be based, questions of translation or 'decoding' must be considered in relation to what follows. In view of this it is hardly surprising that it was in the case of translations of the Bible that Europeans first confronted these issues, and did so precisely in the period which is covered by the present work. In an essay on English translations of the Bible, Gerald Hammond tackled the problems which face all those who attempt to render a text into another language, including those others whose translations have, in certain cases, been used here. In general terms, he notes that "Translation" is one of the most influential forms of literary criticism, for it both interprets and creates the text it addresses. Indeed, in its original uses in English, the word interpret means "translate". He also observes, in this essay, that Idioms are even more embedded in language and culture systems than single words are, so that what is offered is not translation but only an equivalent'. ${ }^{4}$ By way of illustration Hammond recounts some episodes in the controversy, which took place in the 1520s - and 1530s, between two famous English Christian figures, Thomas More, who died as a Catholic because of his refusal to recognise King Henry VIII's supremacy over the Church in England, and William Tyndale, who became an inspiration to Protestants. The issue was the latter's English translation of the Christian New Testament. Tyndale's responses to More's challenges over particular renderings indicate that translators in that period were little troubled by that 'semantic accuracy' which Hammond rightly describes as an illusion. ${ }^{5}$ The point at issue here, though, is nothing less than the very nature of the translations which follow. If historical documents are indeed to be treated with the care and attention normally lavished on what is commonly called 'literature' - novels, poetry, plays, and so on - then the question of 'accuracy' must be addressed from the outset.

In essence, there seem to be two main approaches to translation. In the first case, one can attempt a literal' rendering of the text in hand. This means that the translator should follow, as far as possible, the style and phraseology of the original document, even if they do not convert

4. Gerald Hammond, 'English translations of the Bible', in The literary guide to the Bible, eds Robert Alter and Frank Kermode, London, 1987, p. 649.

5 Hammond, 'English translations', pp. 651-2. 
easily into English expression. The alternative approach is the attempt to produce a translation which does 'read well' in English, even if this means that sentences have to be re-arranged, and forms of expression changed. An illustration of the problems which arise from the need to resolve this issue comes from sixteenth-century debate over the way in which the Holy Scriptures themselves should be translated.

In the thirteenth chapter of Paul's First Letter to the Corinthians, there is a famous passage in which the author describes, to the members of that church, what he saw to be the proper nature of Christian behaviour. The main subject of the earlier verses of this chapter, in the original Greek, agape, is commonly translated either as 'love' or as 'charity'. In his translation, Tyndale uses 'love', but More regarded this as a dangerously 'untheological' word. For him, 'charity' was safer, because it more closely resembled the expression used in the Latin translation, the Vulgate [see document 1 below], which was the version commonly used by the Western Church at the time. The Latin word used here was $c[h]$ aritas. The point is that both men came to the Biblical text with their own purposes and prejudices. More was desperate to preserve the Catholic Church which he knew and loved, and of which the Vulgate (even though it was known by the 1520 s to be based on an inadequate range of texts and to contain 'inaccuracies') was a bastion, while Tyndale believed that the Bible should be freed of deliberate Catholic obstruction, which largely kept it in the hands of the clergy and of the better-educated among the laity, and be given directly to all the Christian people of England. Thus their respective uses of the texts of Scripture were developed under the influence, not only of a desire to render the Biblical text accurately, but also of their individual hopes and fears for the future of the Western Church.

This is just one example of the general truth that all translation depends, not only on the skill and accuracy of the translator, but also on his or her background and approach to the task. However, the effect and effectiveness of a translation also depend on the skill and background of the reader. ${ }^{6}$ Each word is like a package of associations and memories, which speaks differently to each person, and yet an inner core of 'accuracy', in the sense of a common Judæo-Christian history and heritage, exists throughout. It would be unduly presumptuous to suggest that a happy balance between literal accuracy and lively interpretation has been achieved in the translations which follow [at least those for which

6 The General Introduction and the Bibliography of Printed Works Cited are intended to help the reader in this respect. 
the present author is responsible], but the varied registers of language which are used in these texts are intended to do as much as possible to convey what appears to be the sense of the original. This means that the English versions offered here must attempt to reflect, for example, the language of Papal lawyers, or else that of government draughtsmen, or of private citizens making personal and business arrangements, or of preachers, theologians, novelists and poets. Many of these texts are clearly the work of one author, who is named, but the various ecclesiastical and secular legal documents, which are included in the collection, do not have undisputed authorship. Yet, if 'historical' documents are indeed to be treated as what they in fact are, that is, 'literary' texts, then the problem of authorship, which has so vexed scholars and critics in recent years, ${ }^{7}$ must be addressed, if a suitable kind of language is to be used to translate them.

None of these documents is straightforward. As I wrote some years ago,

It must be evident, at the most basic level, to both the historian and the literary scholar, that even the most common words, such as rey [king] or señorio [lordship] are not immutable in meaning, and have to be considered not only in their textual uses, but also in the circumstances in which the texts which employ them were produced. ${ }^{8}$

Nowhere are these words more applicable than to the religious vocabulary, with its diverse Jewish and Christian understandings and interpretations, which fills so many of these documents. As for their historical context, the General Introduction and the shorter introductions to the chapters, attempt to address the matter. The reader should, however, bear in mind throughout George Steiner's warning.

The historian's problem as to what he is talking about is a genuine one. $\mathrm{He}$ must not only 'explain' his document, i.e. paraphrase, transcribe, gloss it at the lexical-grammatical level, but also 'understand' it, i.e. show 'how what was said was meant and thus what relations there may have been between various different statements within the same general context'. And the meaning thus arrived at must be the 'true one'. By what metamorphic magic is the historian to proceed? ${ }^{9}$

7 See, for example, Ann Jefferson and David Robey, Modern literary theory. A comparative introduction (London, 1982).

8 John Edwards, 'Conversos, Judaism and the language of monarchy in fifteenth-century Castile', in Circa 1492. Proceedings of the Jerusalem Colloquium: Littera Judaorum in Terra Hispanica [1984], ed. Isaac Benabu (Jerusalem, 1992 [1993]), p. 209.

9 Steiner, After Babel, pp. 135-6, including a quotation from Quentin Skinner, 'Meaning and understanding in the history of ideas', History and Theory, vii (1969), p. 47. 
To turn to more mundane matters, a glossary is provided, to help with some of the more specialised vocabulary which has to be used. The first use in the text of each of the terms included in the glossary is marked by the use of bold type. Also, where translated passages involve cuts or omissions from the full text, the usual symbol, '...', is included and, where explanatory material has been inserted into the text, it has been placed in square brackets. The wide range of languages in which these documents originated, together with the diversity of the countries and regions to which they refer, inevitably raises, for the translator, the problem of how to render personal and place names. The general principle followed here has been to use English versions of placenames where they exist, leaving the rest in the original. As is common in historical writing, personal names have also normally been left in their original form, but rulers' names have been anglicised where possible and appropriate.

It is hoped that the words of these texts have been 'unpacked' sufficiently to allow at least some of the experience of Jews and Christians in fifteenth- and sixteenth-century Europe to be conveyed to those with experience of another and later century.

\section{Acknowledgements}

The author wishes to acknowledge the following copyright-holders:

Extracts from

- the Jerusalem Bible: Darton, Longman \& Todd

- the Vulgate Bible: EDICA S.A., Madrid (Biblioteca de Autores Cristianos)

Other extracts listed by document number

3A: Sociéte d'Editions 'les Belles Lettres', Paris

3B: Ecole Practique des Hautes Etudes, Paris, and Mouton et Cie, Paris and the Hague

4A \& B: The Regents of the University of California

4C: Editions Galilée, Paris

5A: Magnes Press, Hebrew University of Jerusalem

7, 9, 21, 29B, 30, 35C, 38, 40B, 44A and B, 45, 47: Pontifical Institute of Medieval Studies, Toronto

11: Author and Institución Fernando el Católico, Zaragoza

19: Magnes Press, Hebrew University of Jerusalem

29A, 46: Nischi-Lischi, Pisa

34: Brill, Leiden

40C: Abaris Books, New York

41A and B: Fortress Press, Philadelphia

43: Yale University

48: Clásicos Castalia, Madrid

49: Princeton University Press

Copyright in the following belongs to their respective authors: documents $5 \mathrm{~B}, 17,20$, $24 \mathrm{~B}, 31 \mathrm{~B}, 37 \mathrm{~A}$ and $\mathrm{B}$.

All other extracts are believed to be out of copyright. Every effort has been made to contact copyright-holders; in case of oversight, please inform the publisher. 